
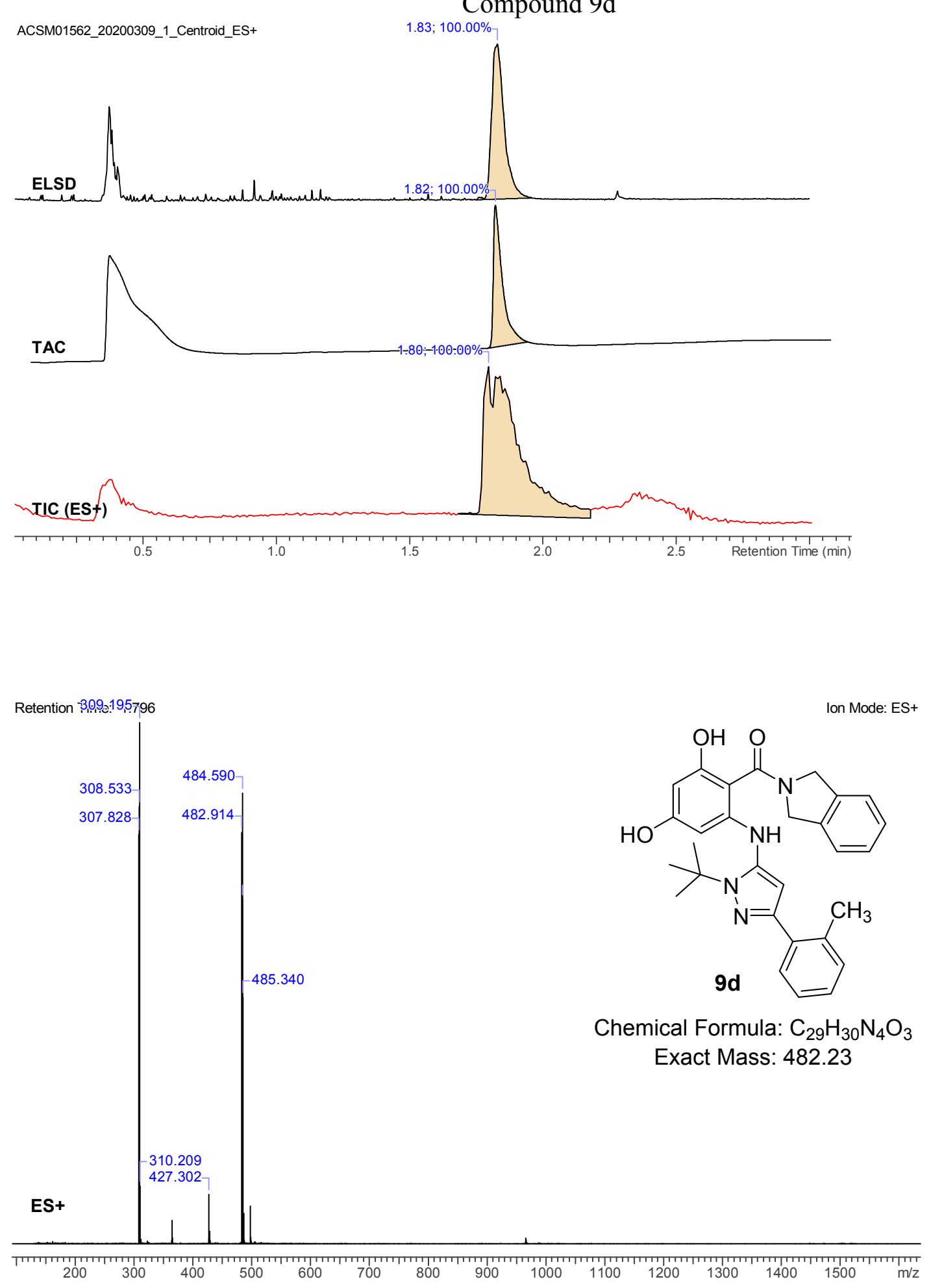


\section{Compound 9j}
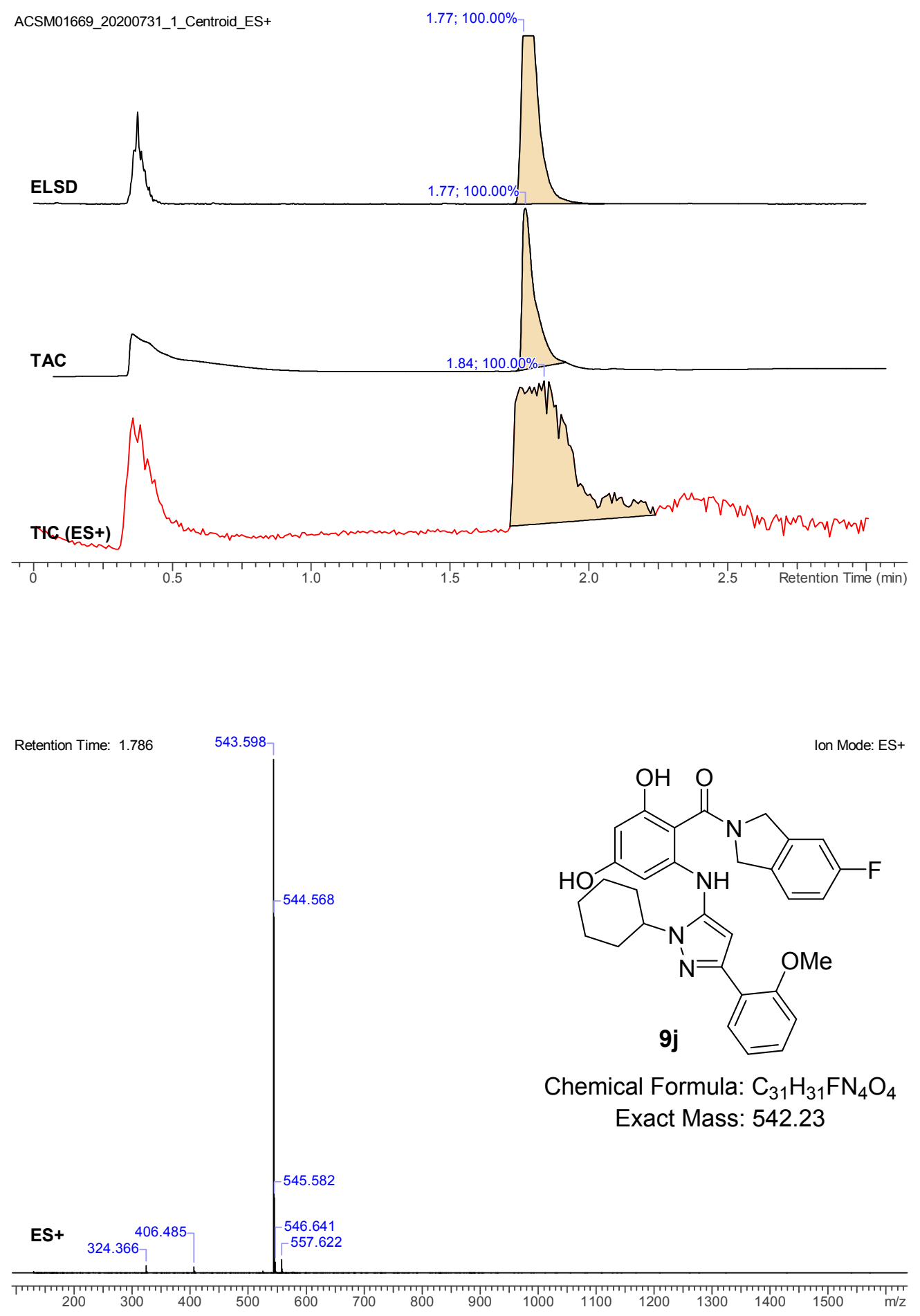


\section{Compound 9o}
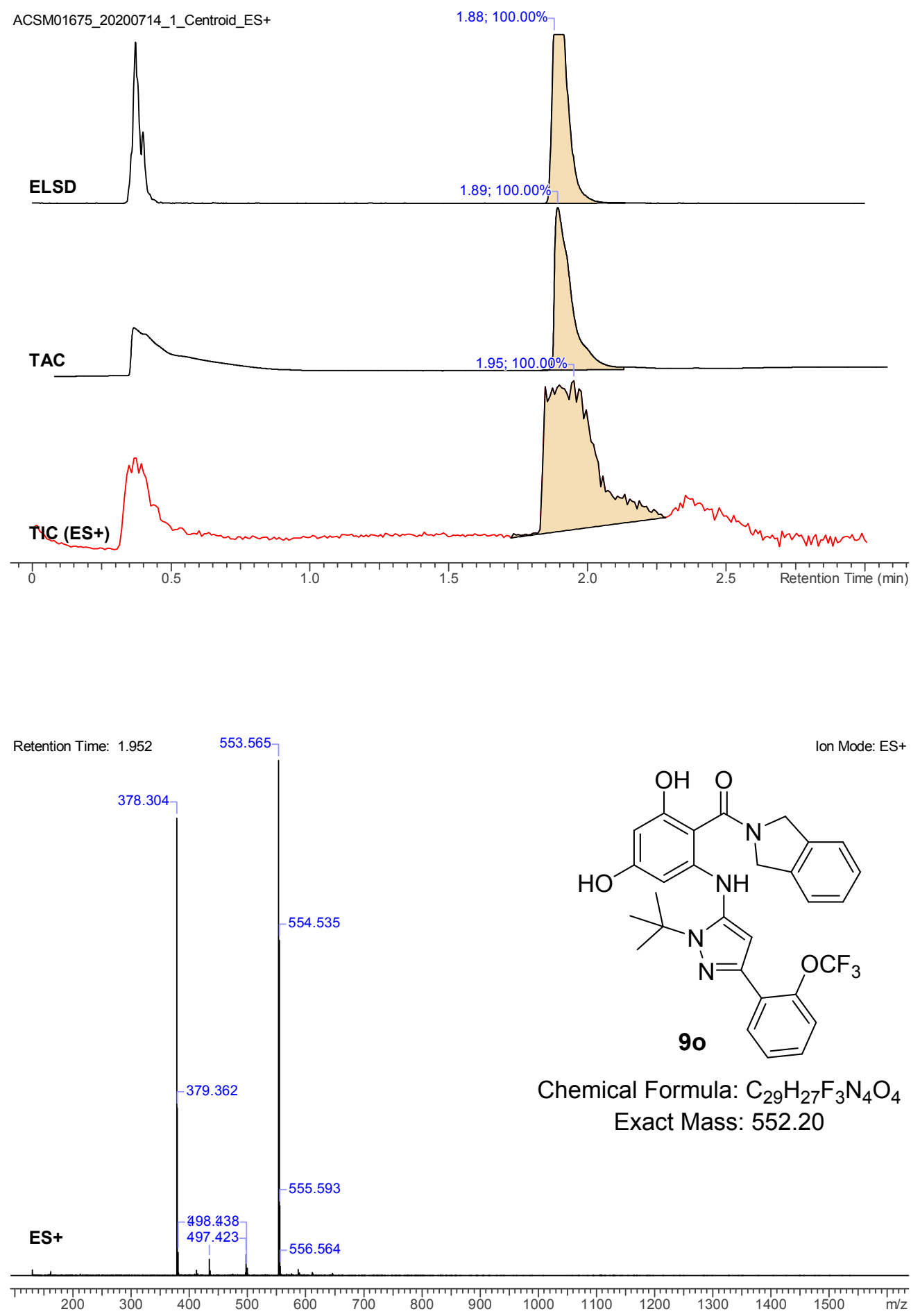


\section{Compound 9v}
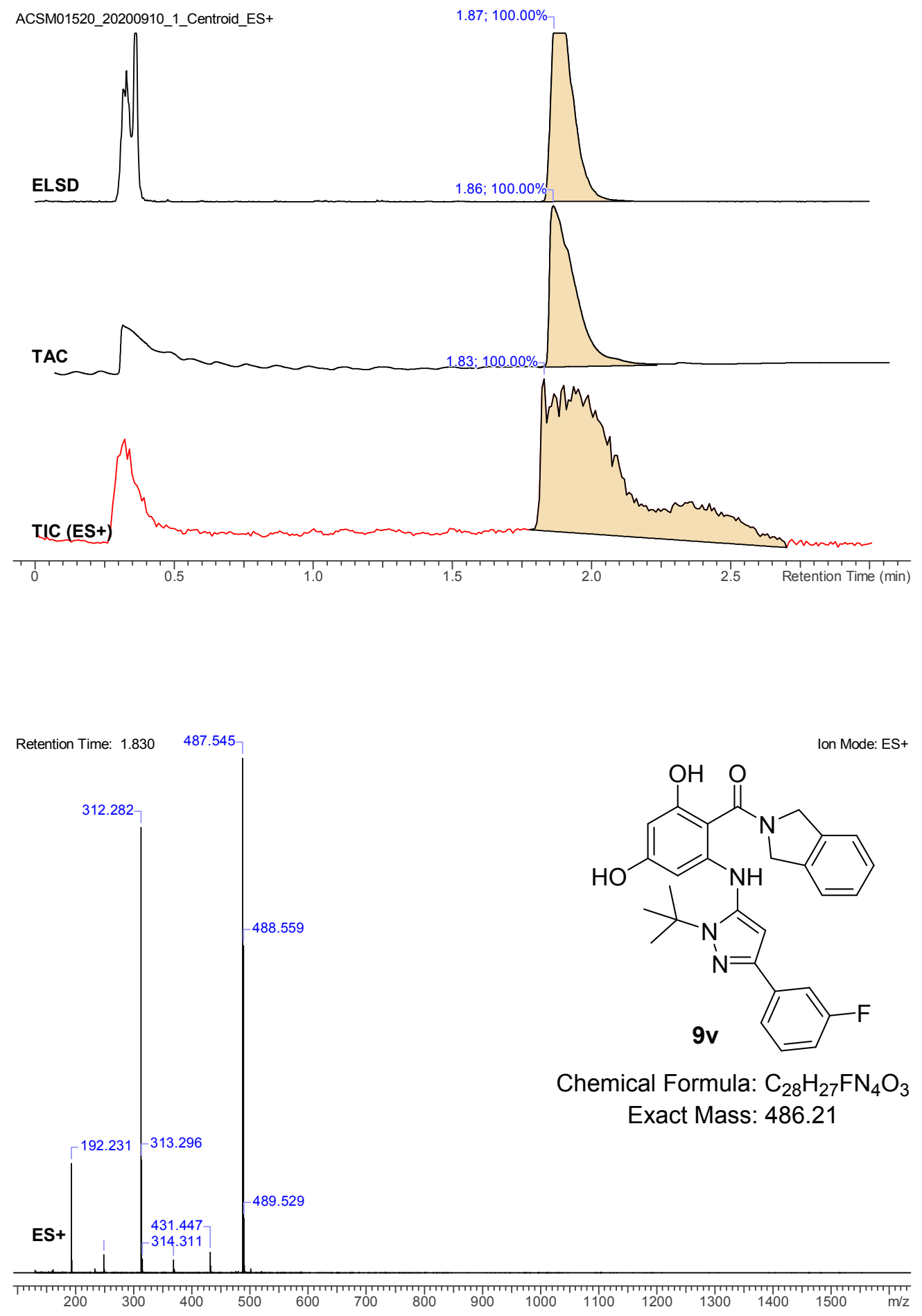


\section{Compound 9ac}
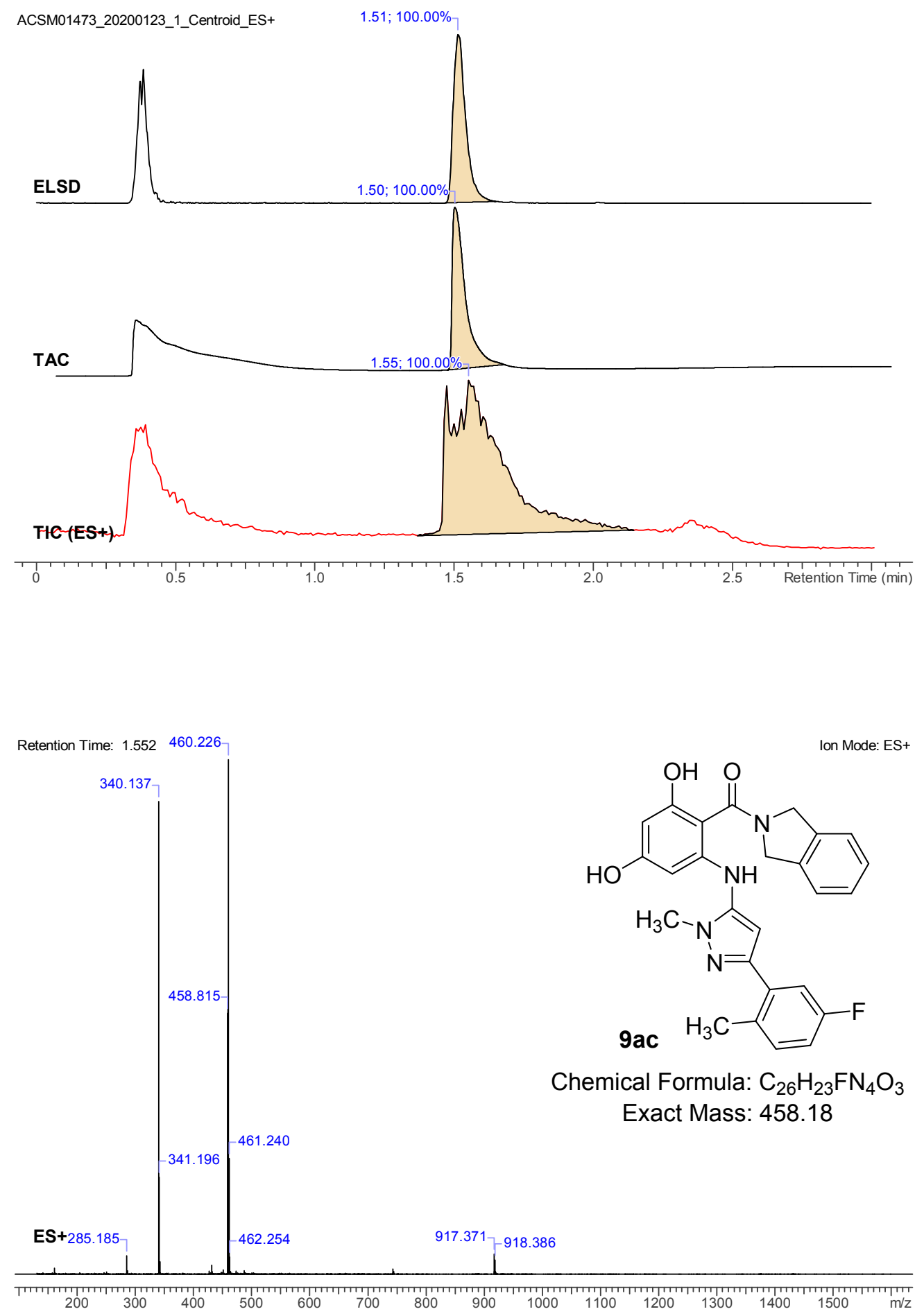


\section{Compound 9ad}
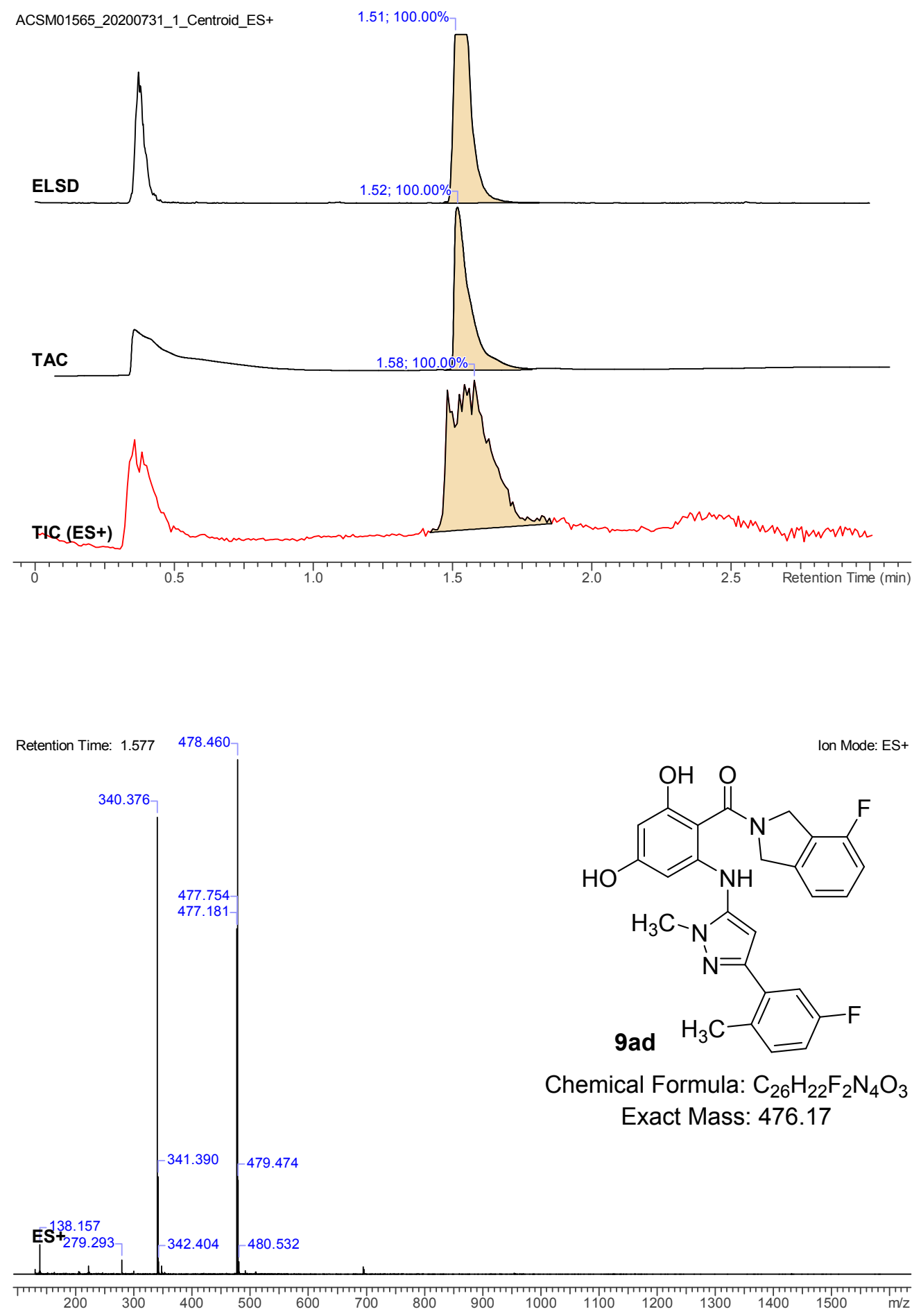


\section{Compound 9ae}
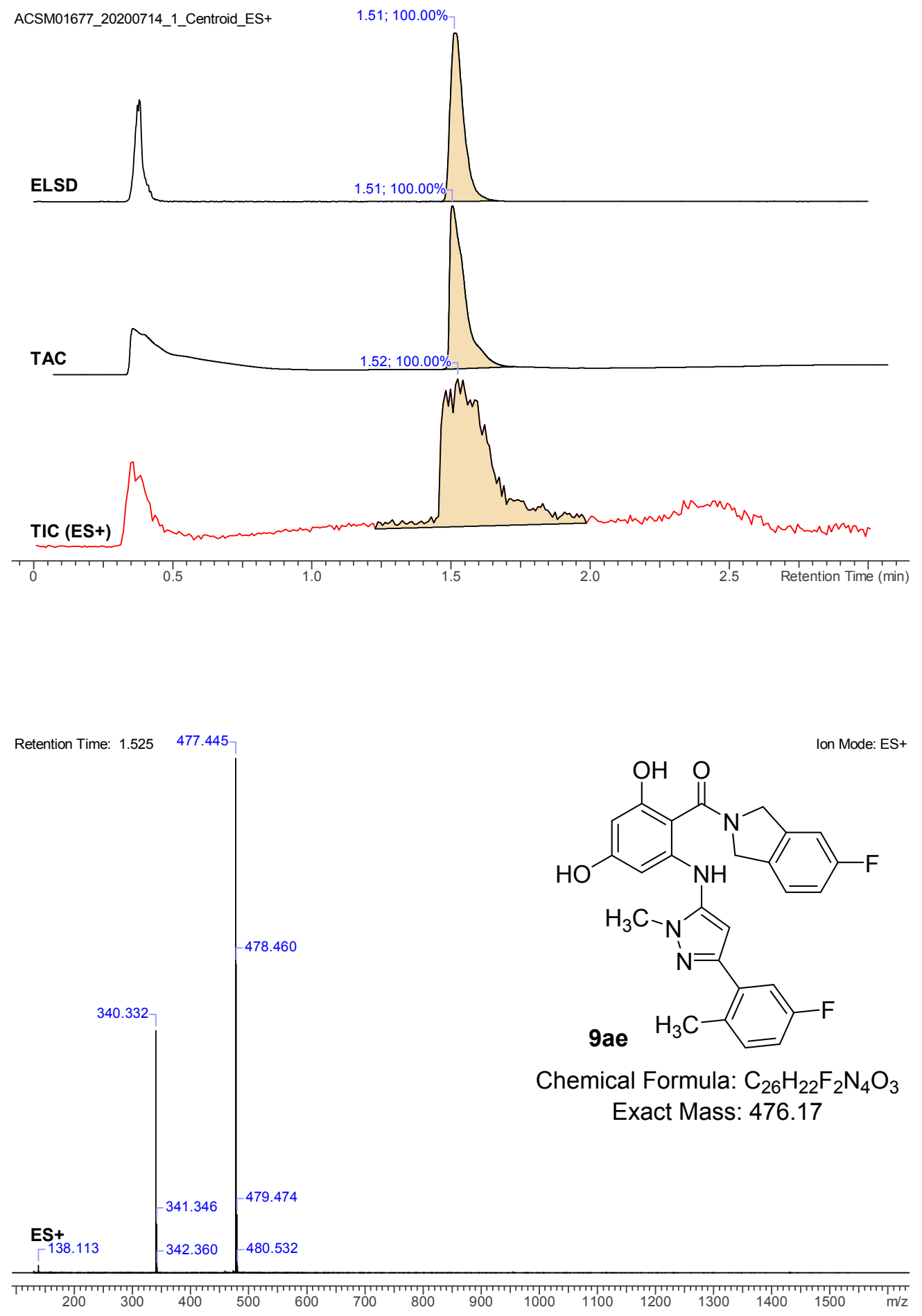


\section{Compound 9af}
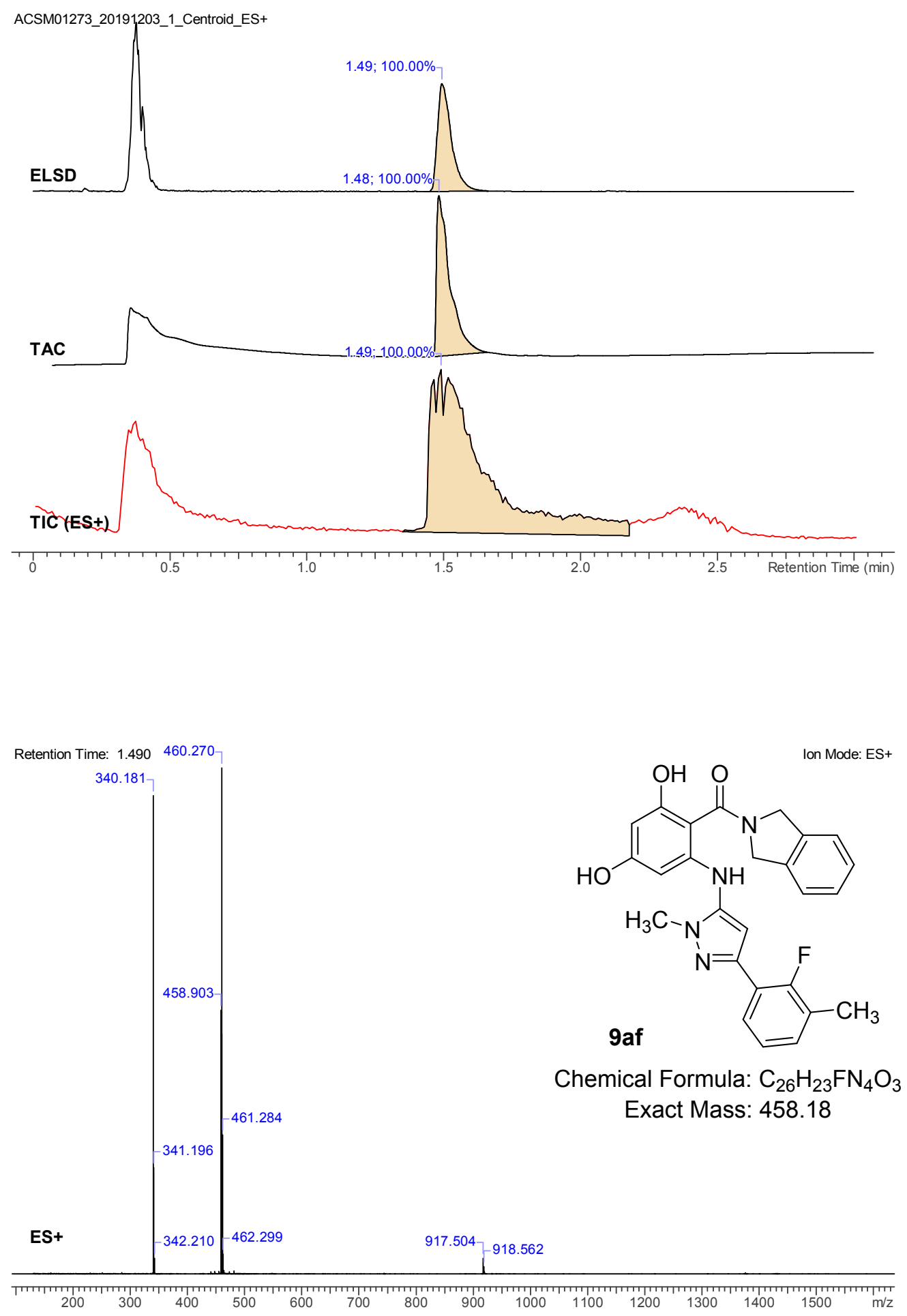


\section{Compound 9ah}
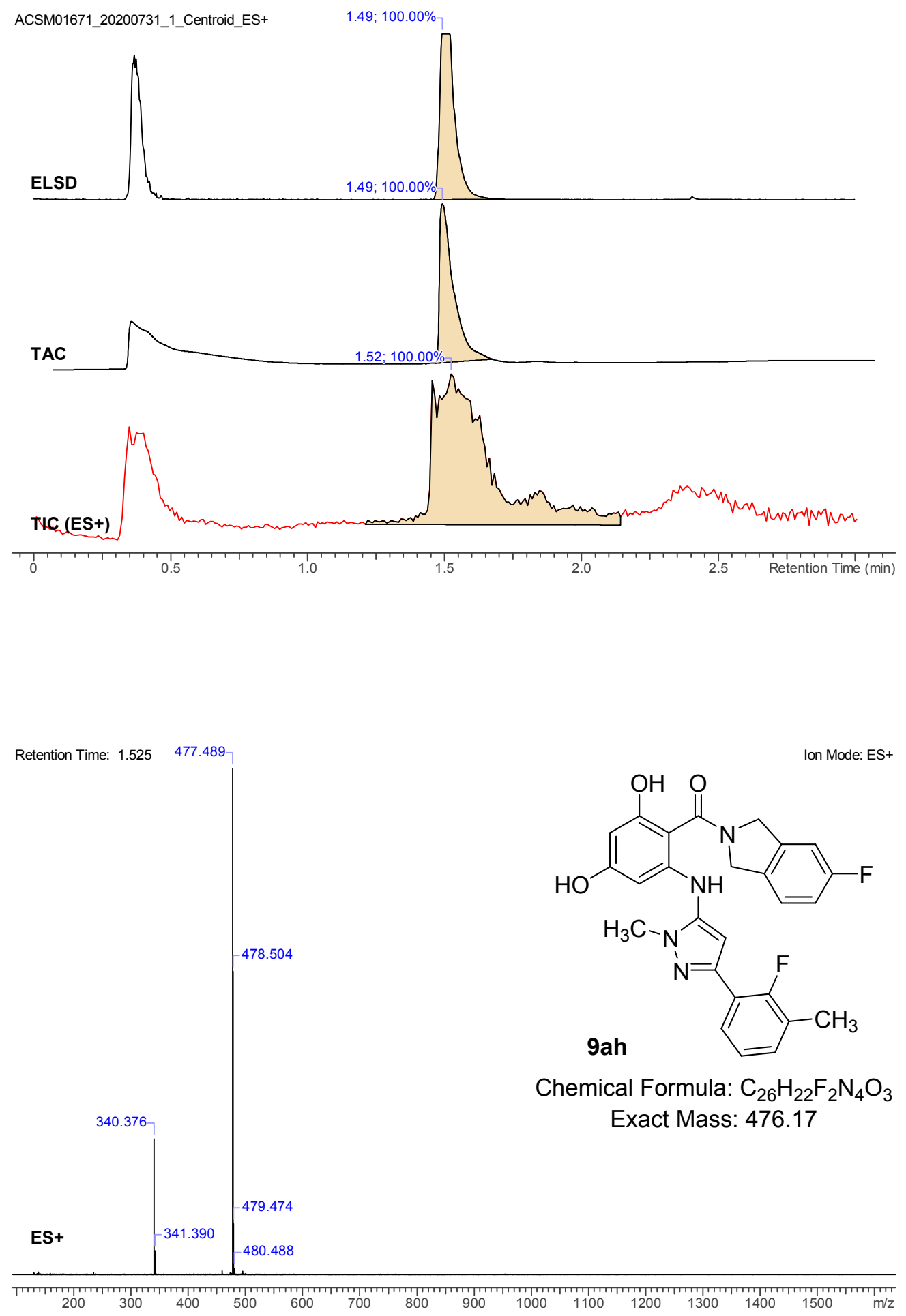


\section{Compound 9ak}
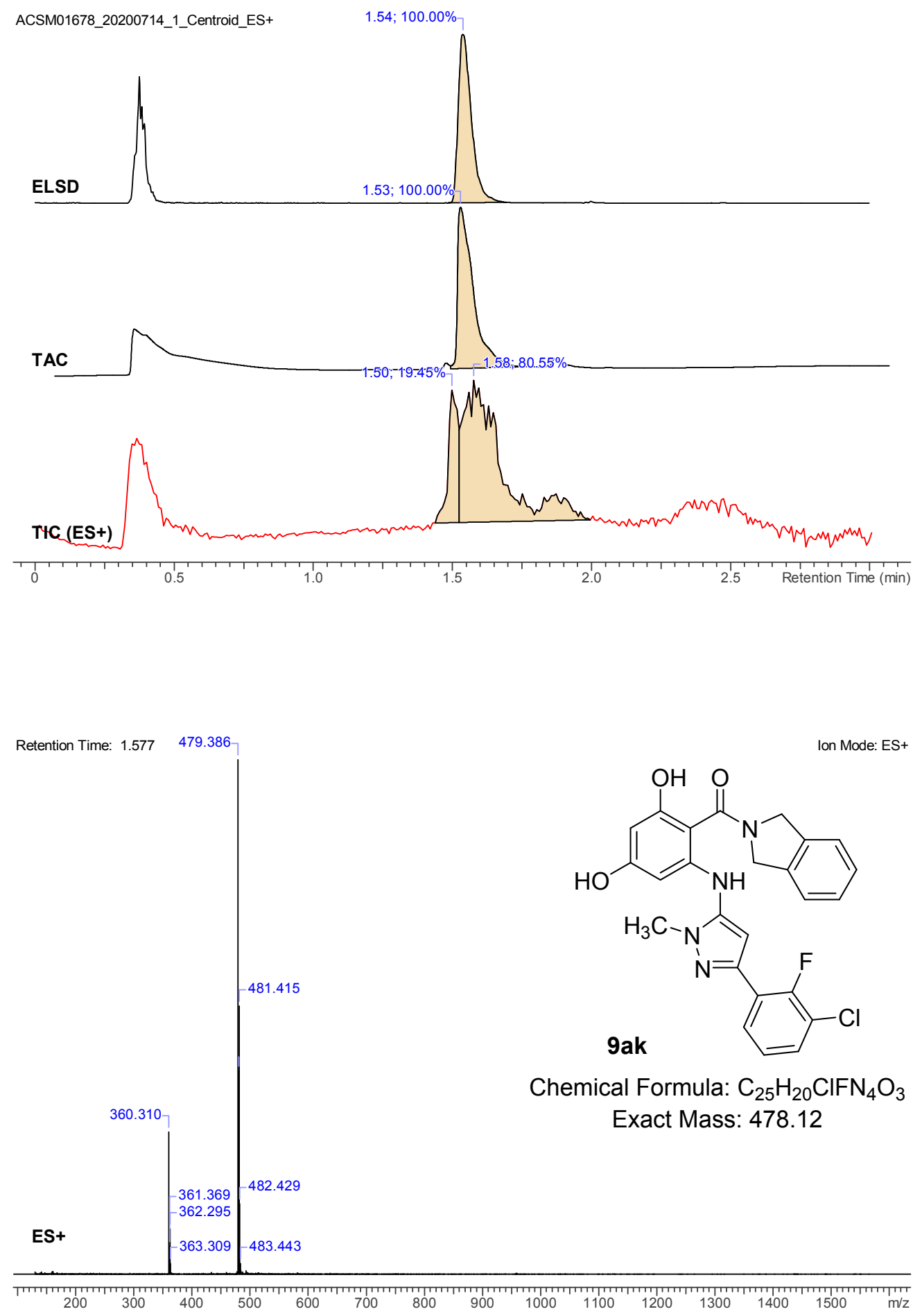


\section{Compound 9am}
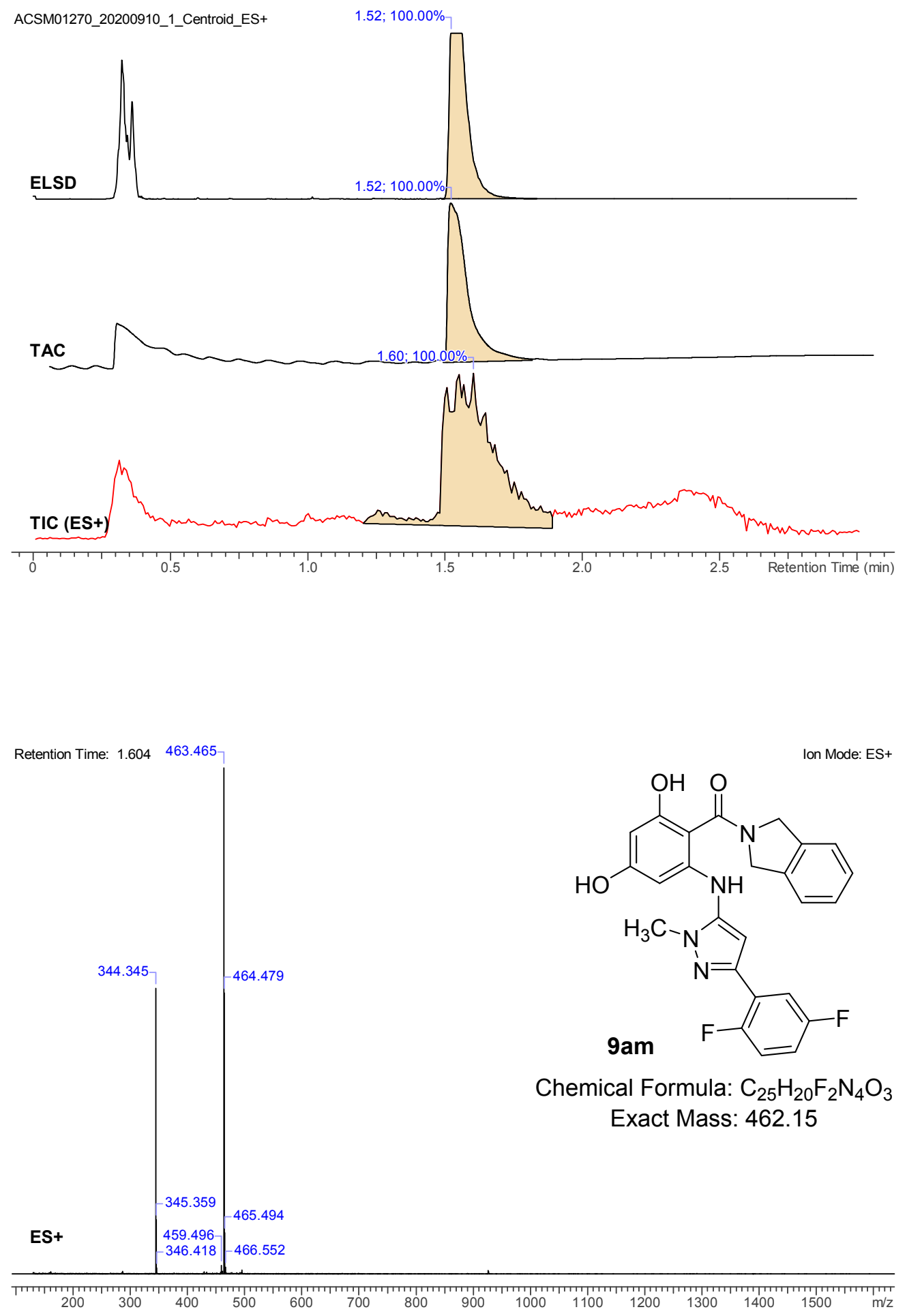


\section{Compound 9an}
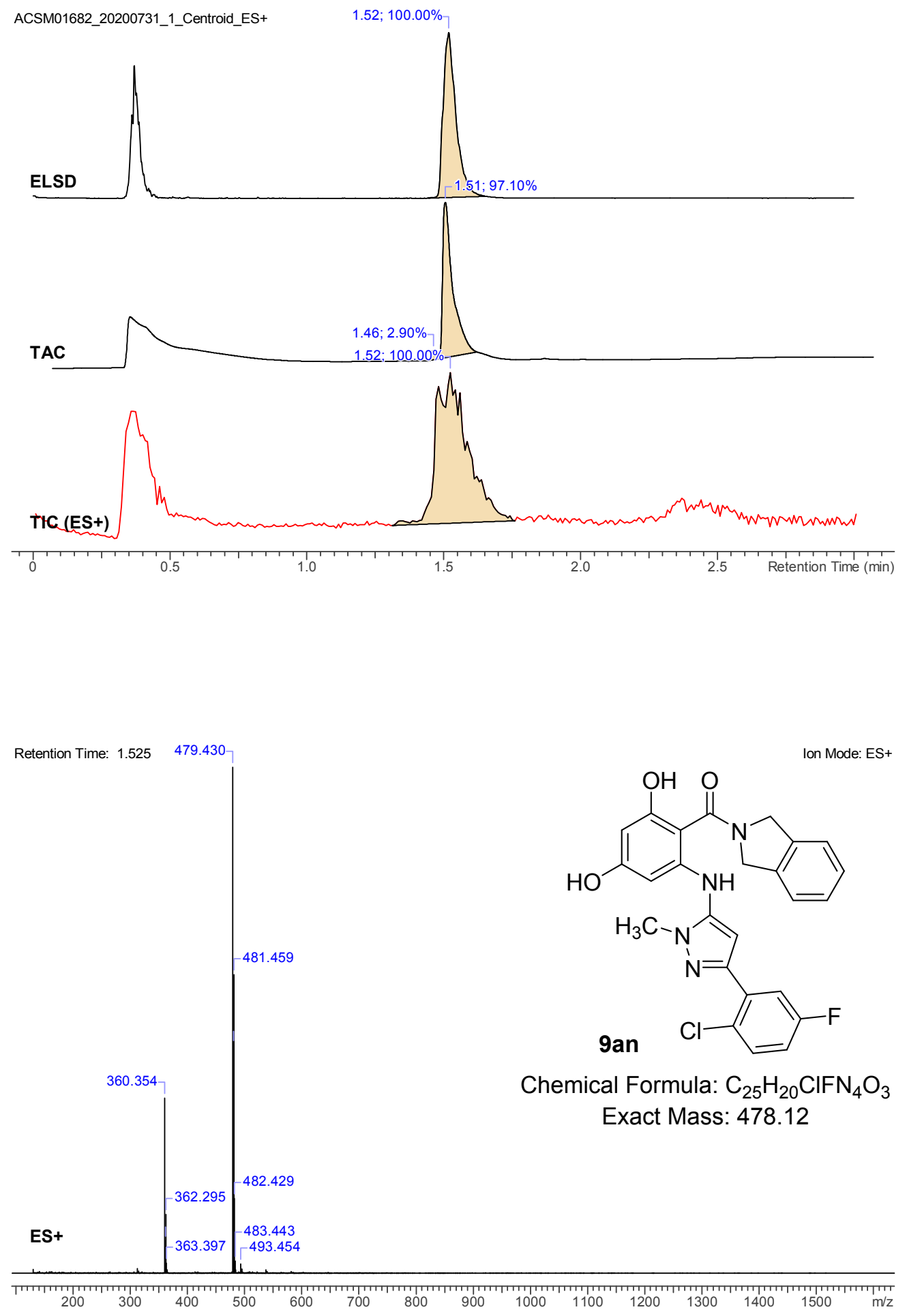


\section{Compound 9ar}
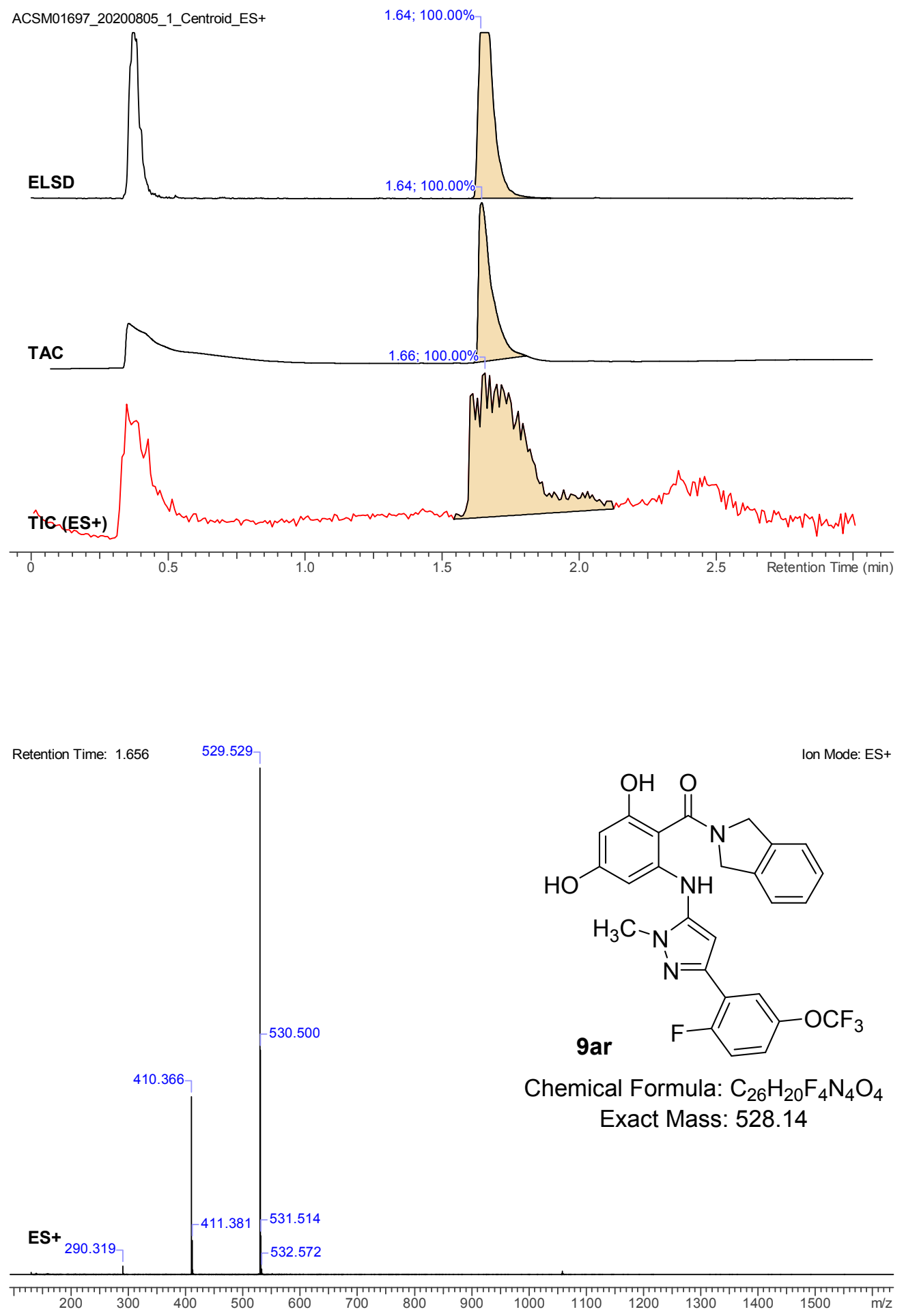


\section{Compound 9av}
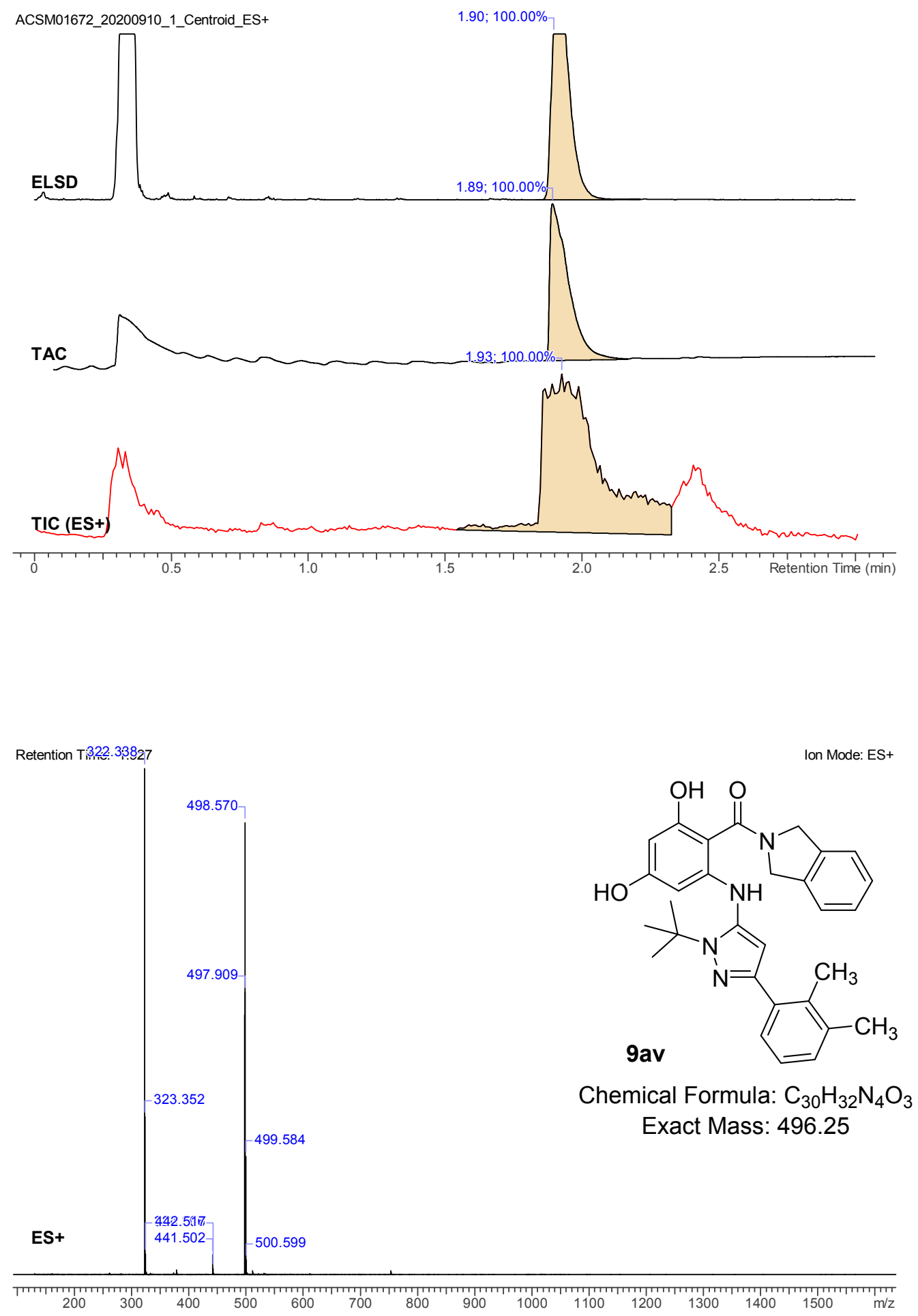


\section{Compound 9ax}
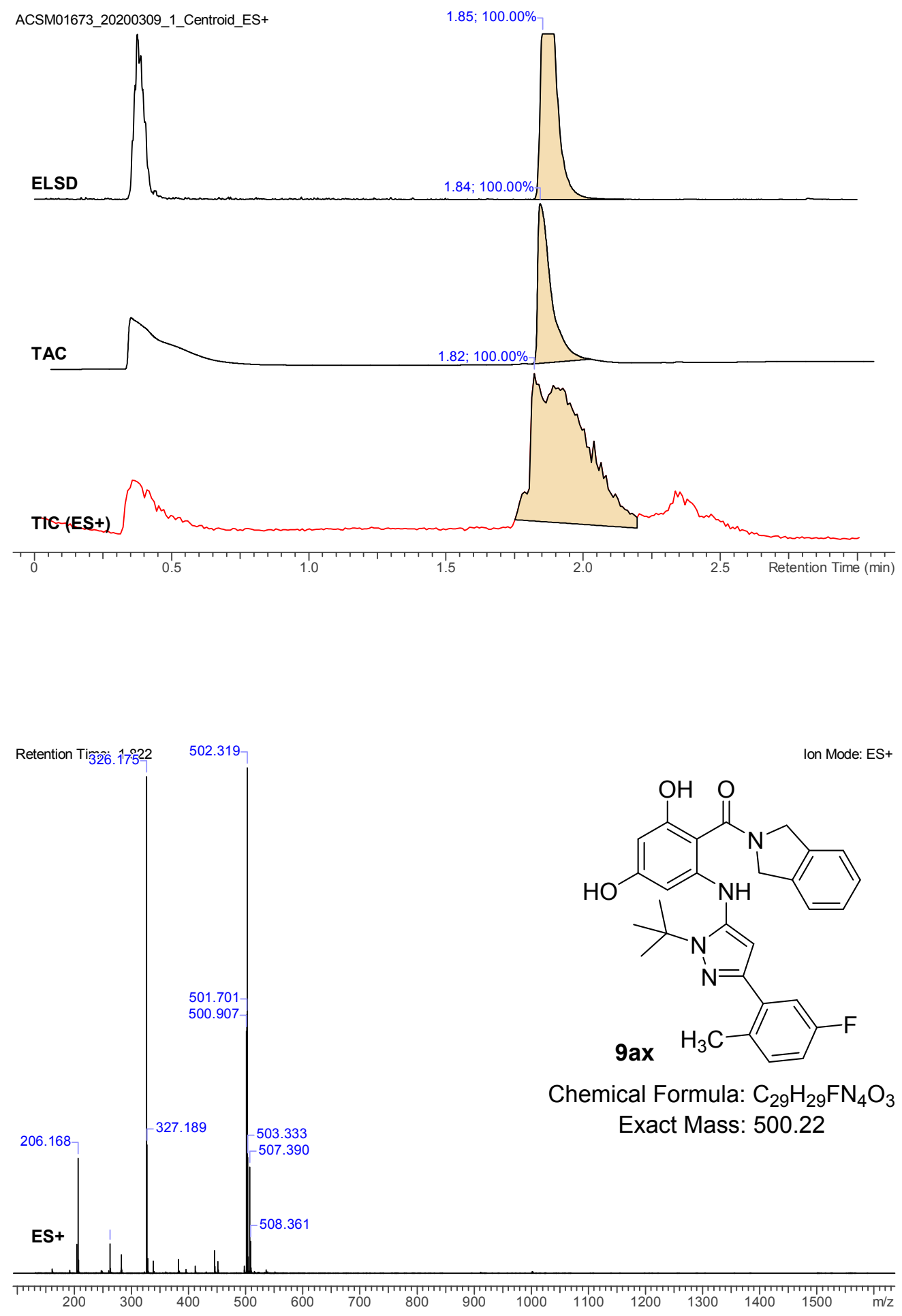


\section{Compound 9az}
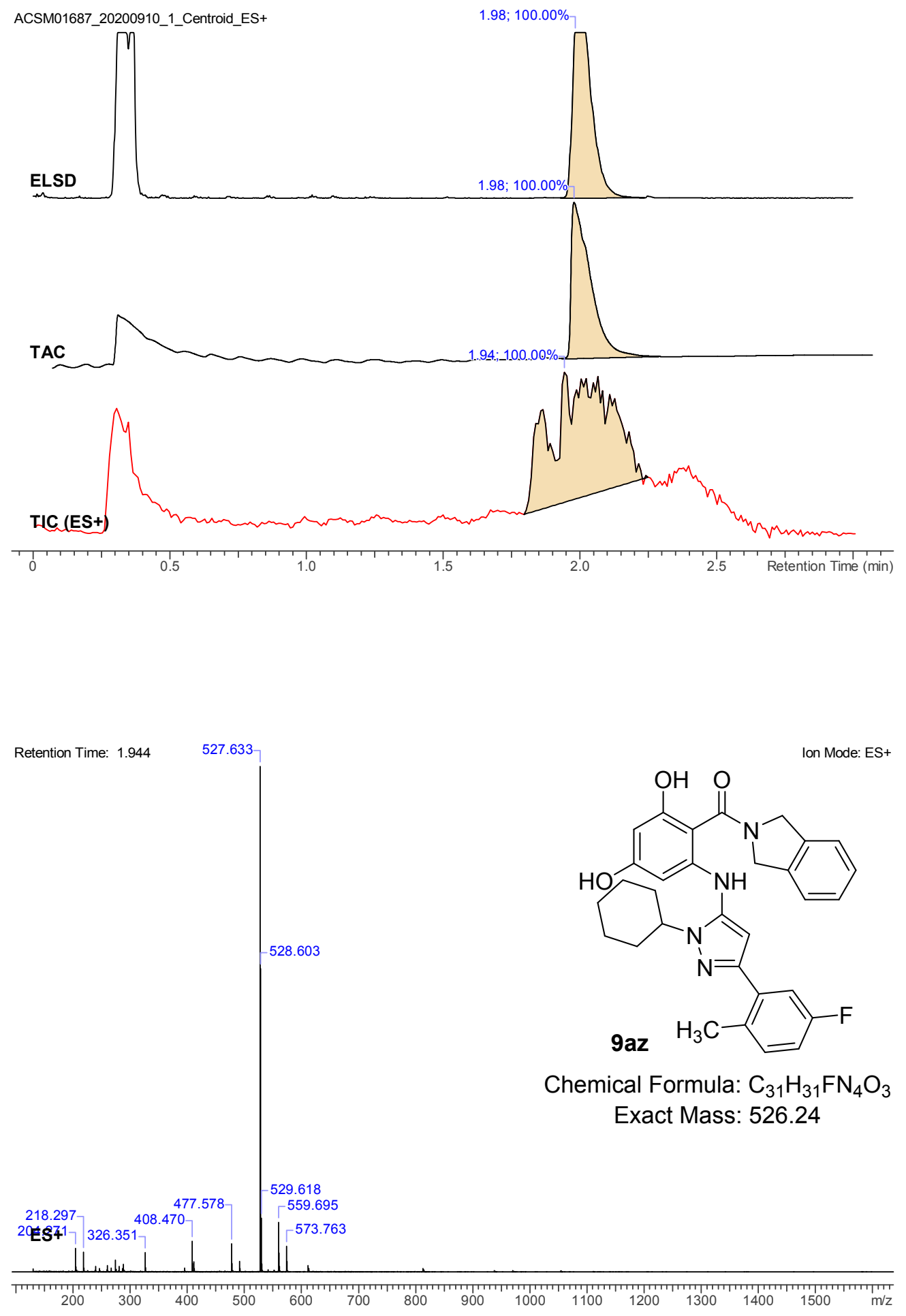


\section{Compound 9ba}
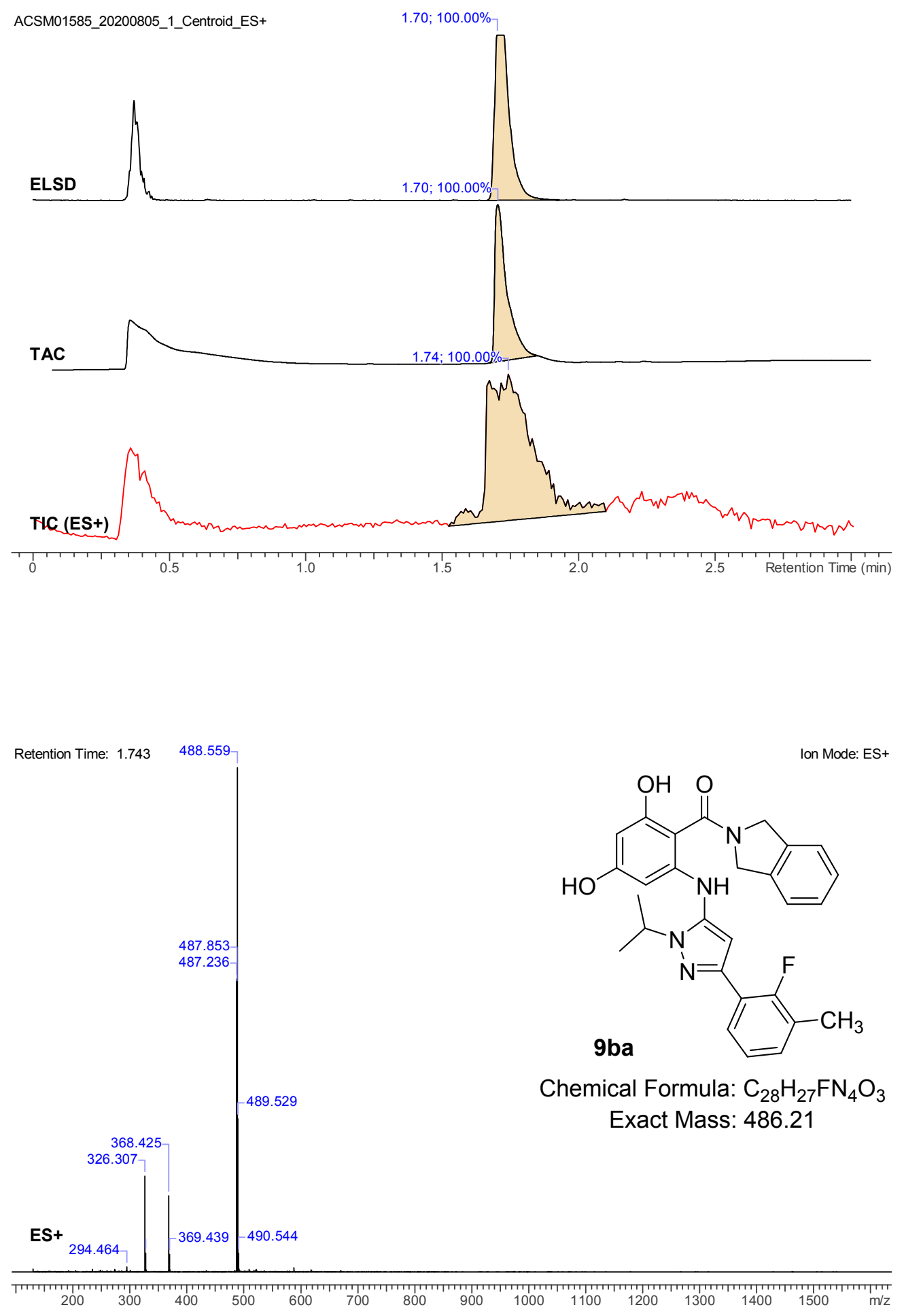


\section{Compound 9bb}
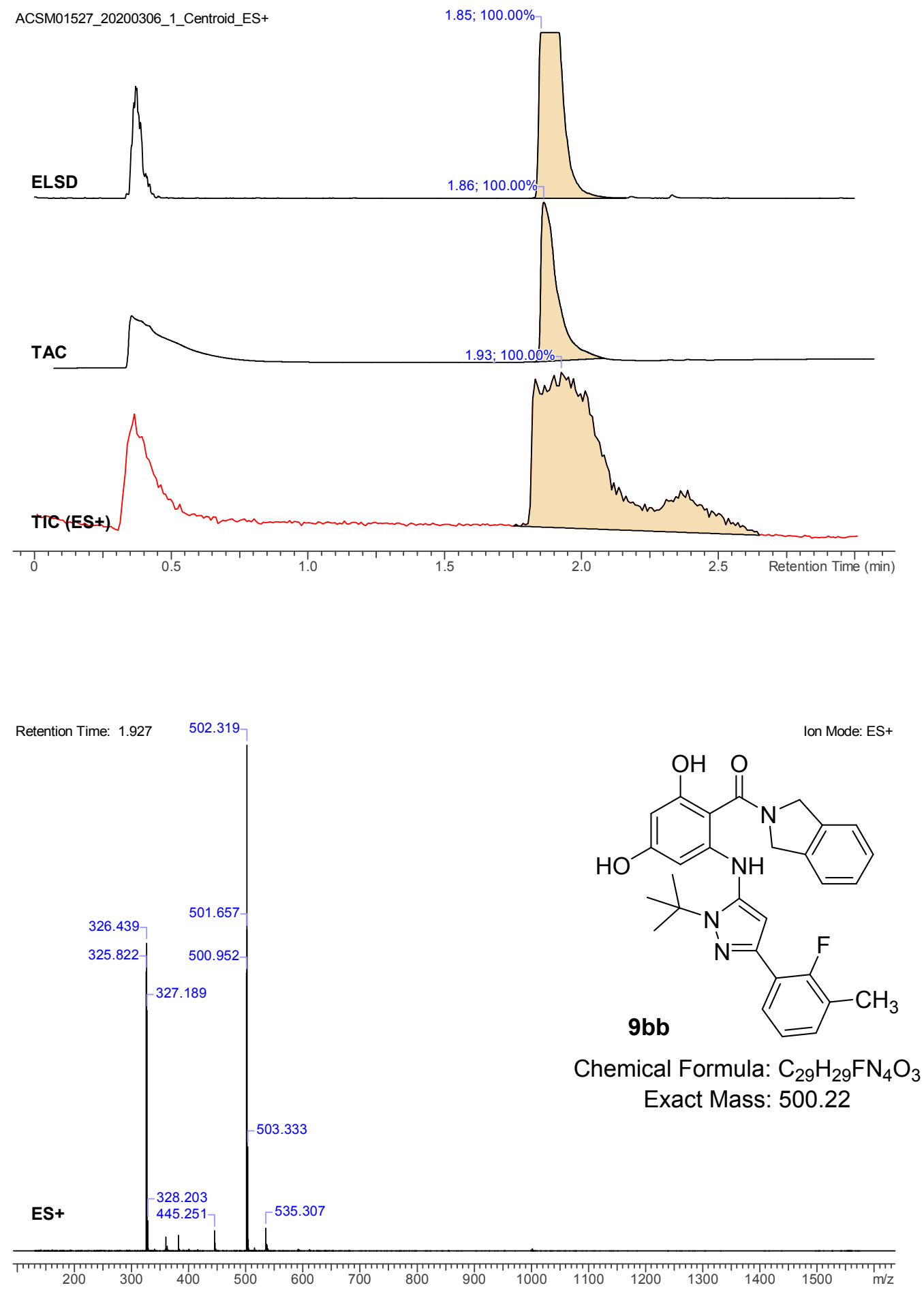


\section{Compound 9bc}
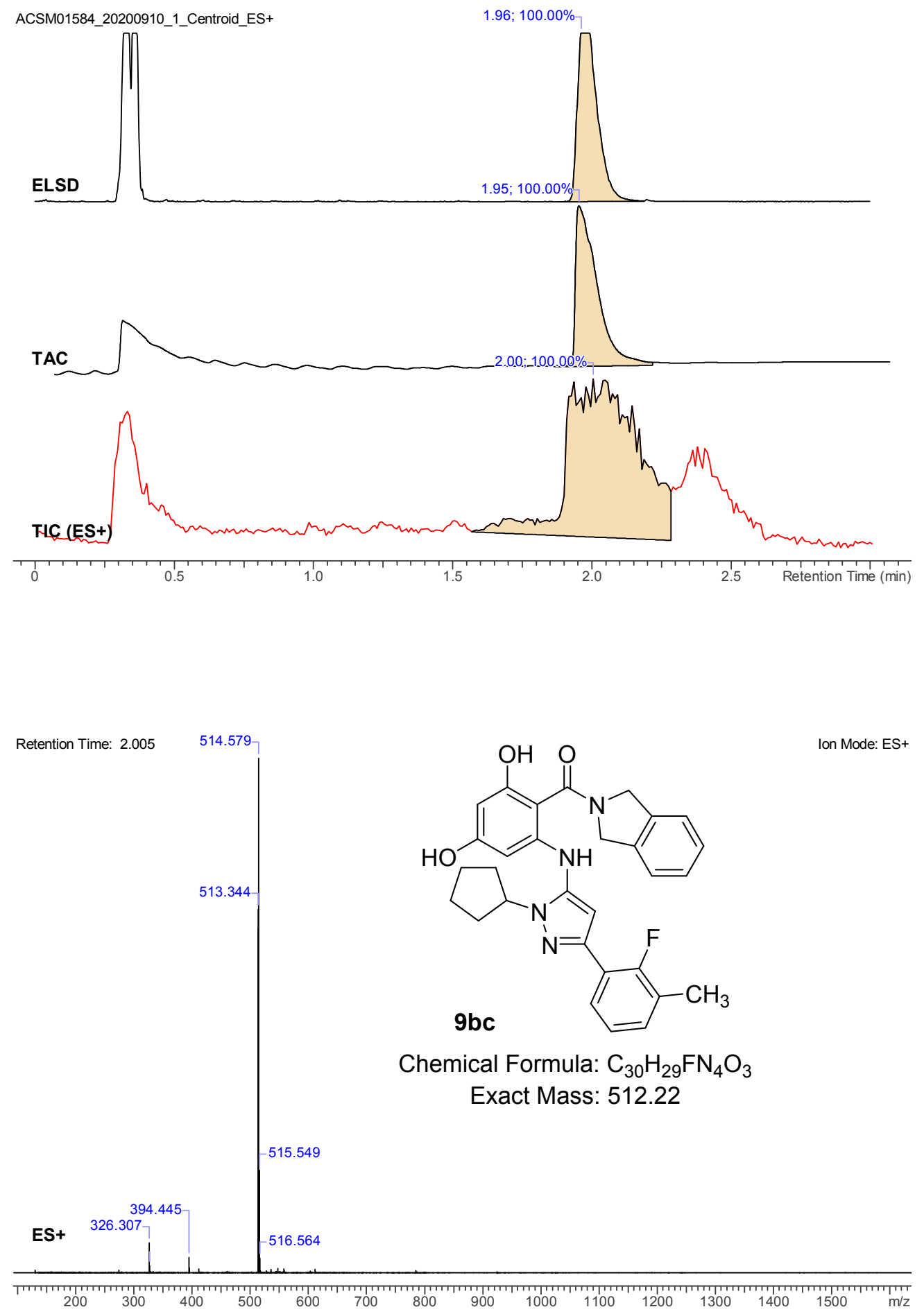


\section{Compound 9bd}
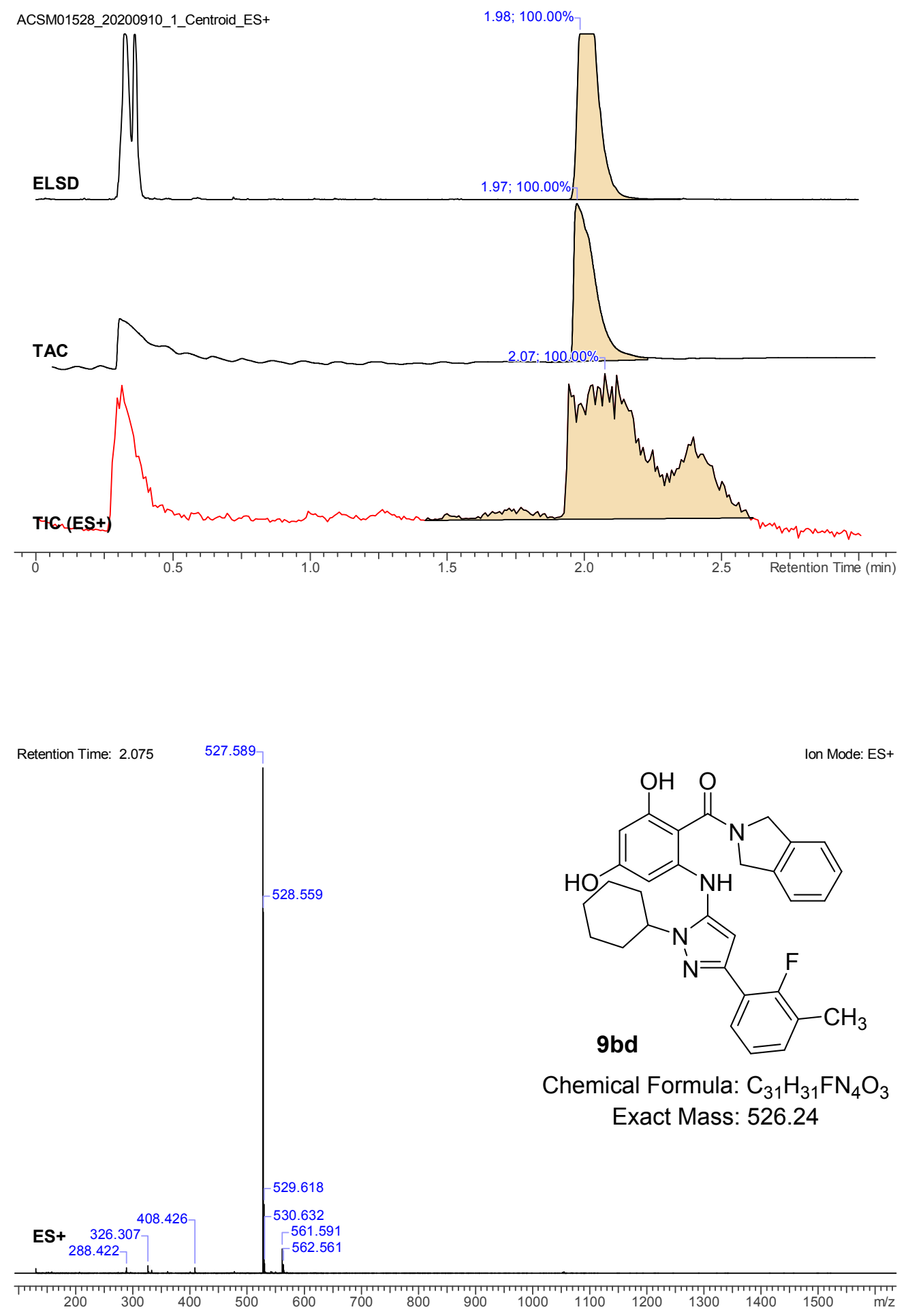


\section{Compound 9be}
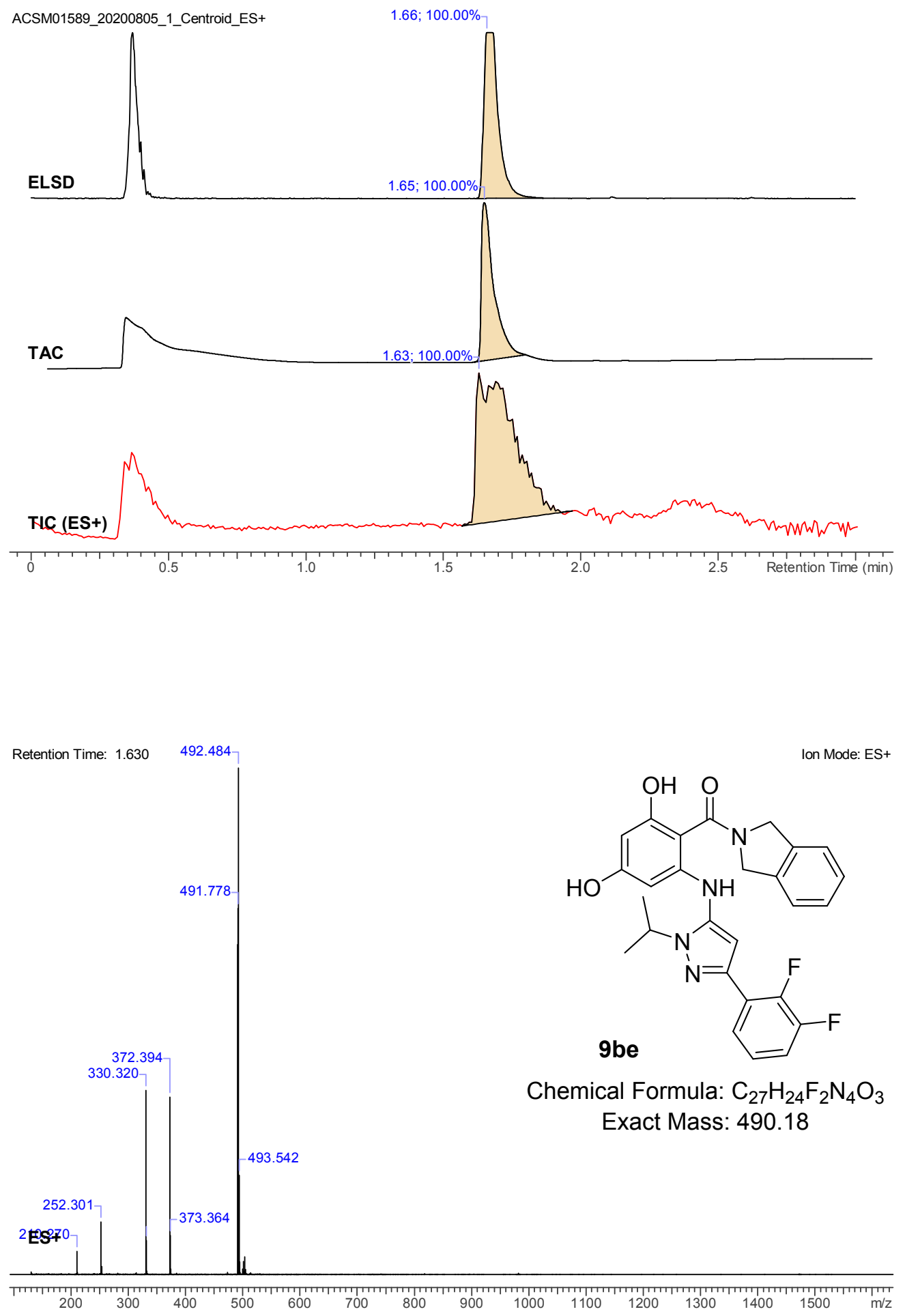


\section{Compound 9bf}
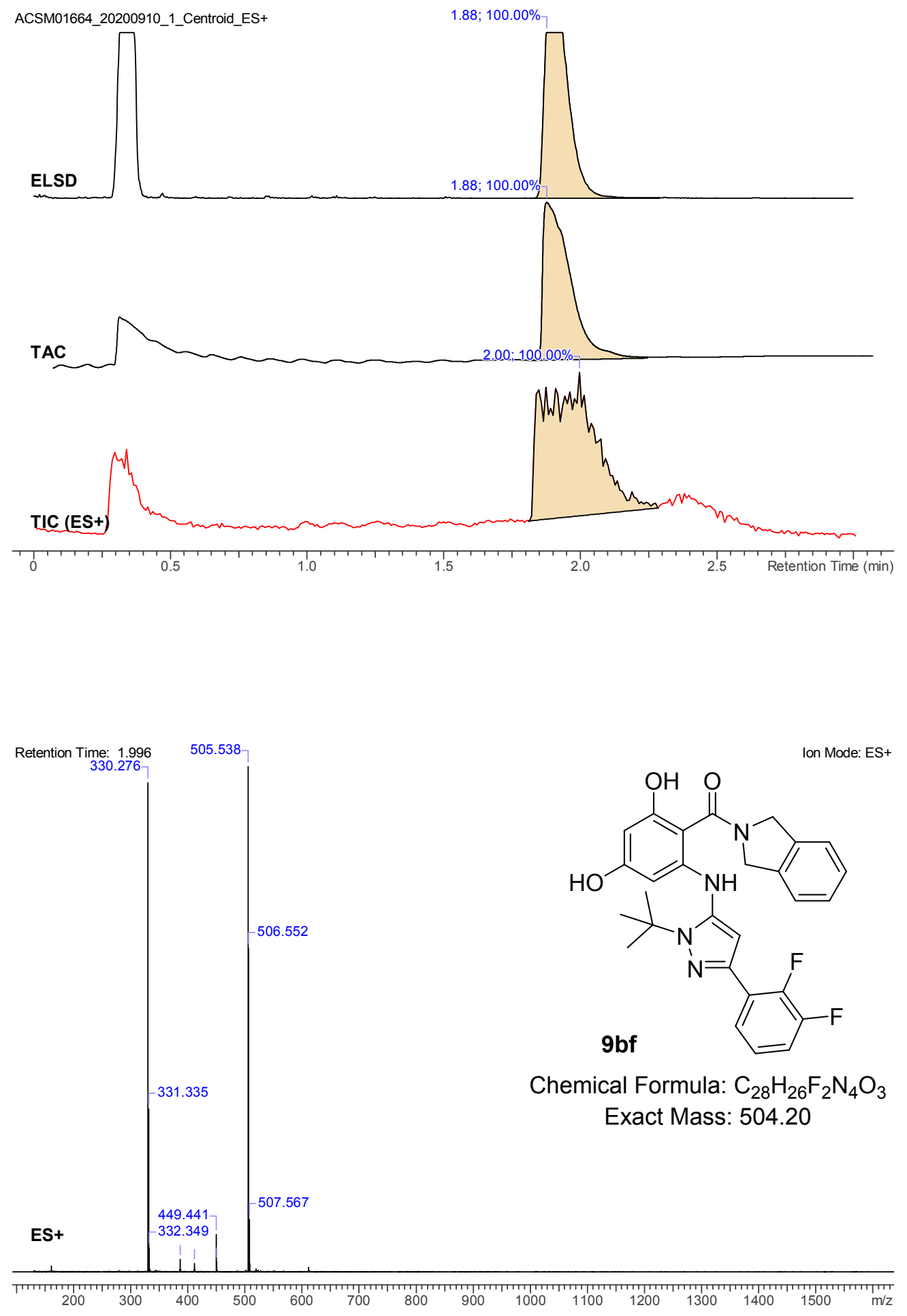


\section{Compound 9bg}
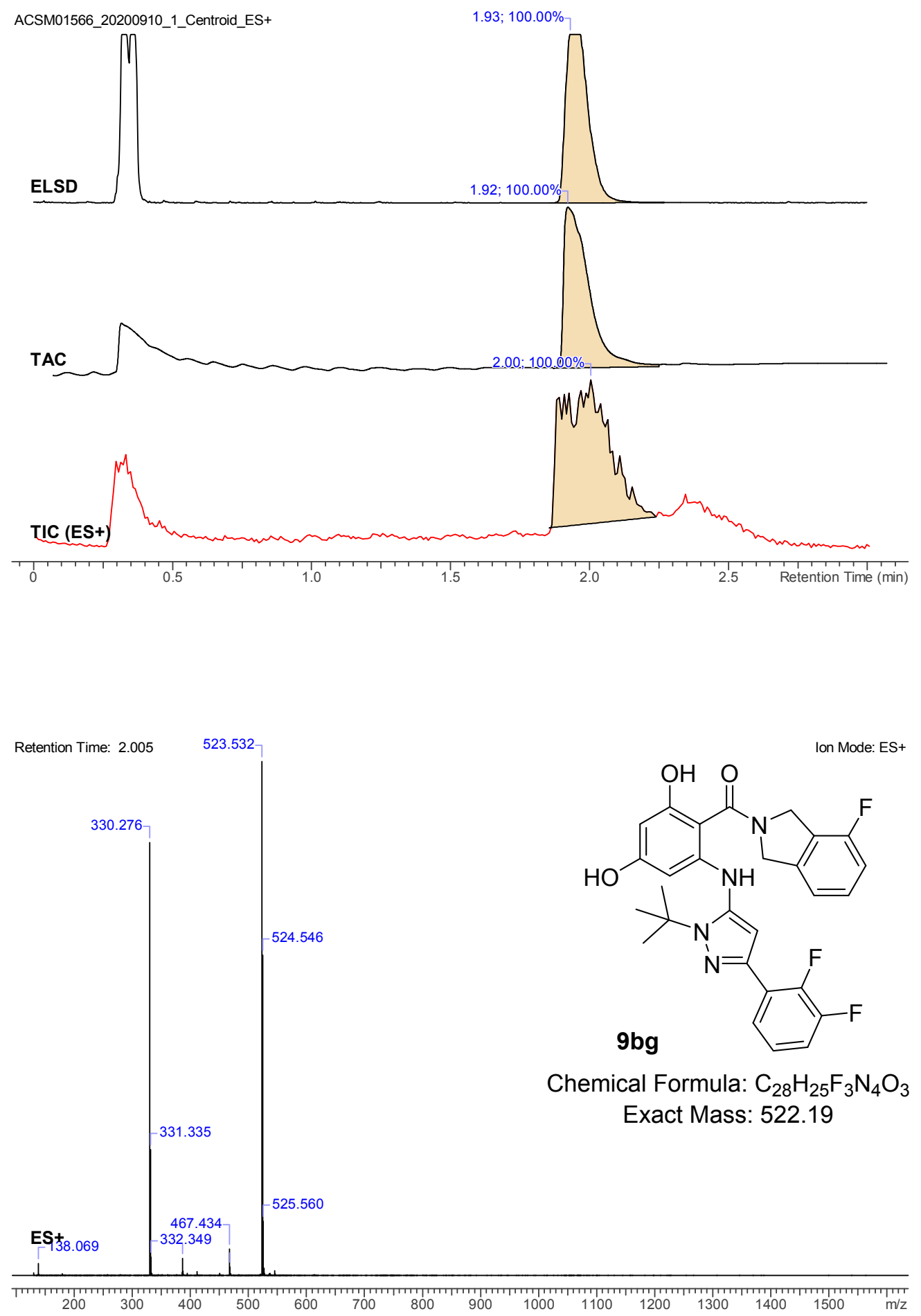


\section{Compound 9bi}
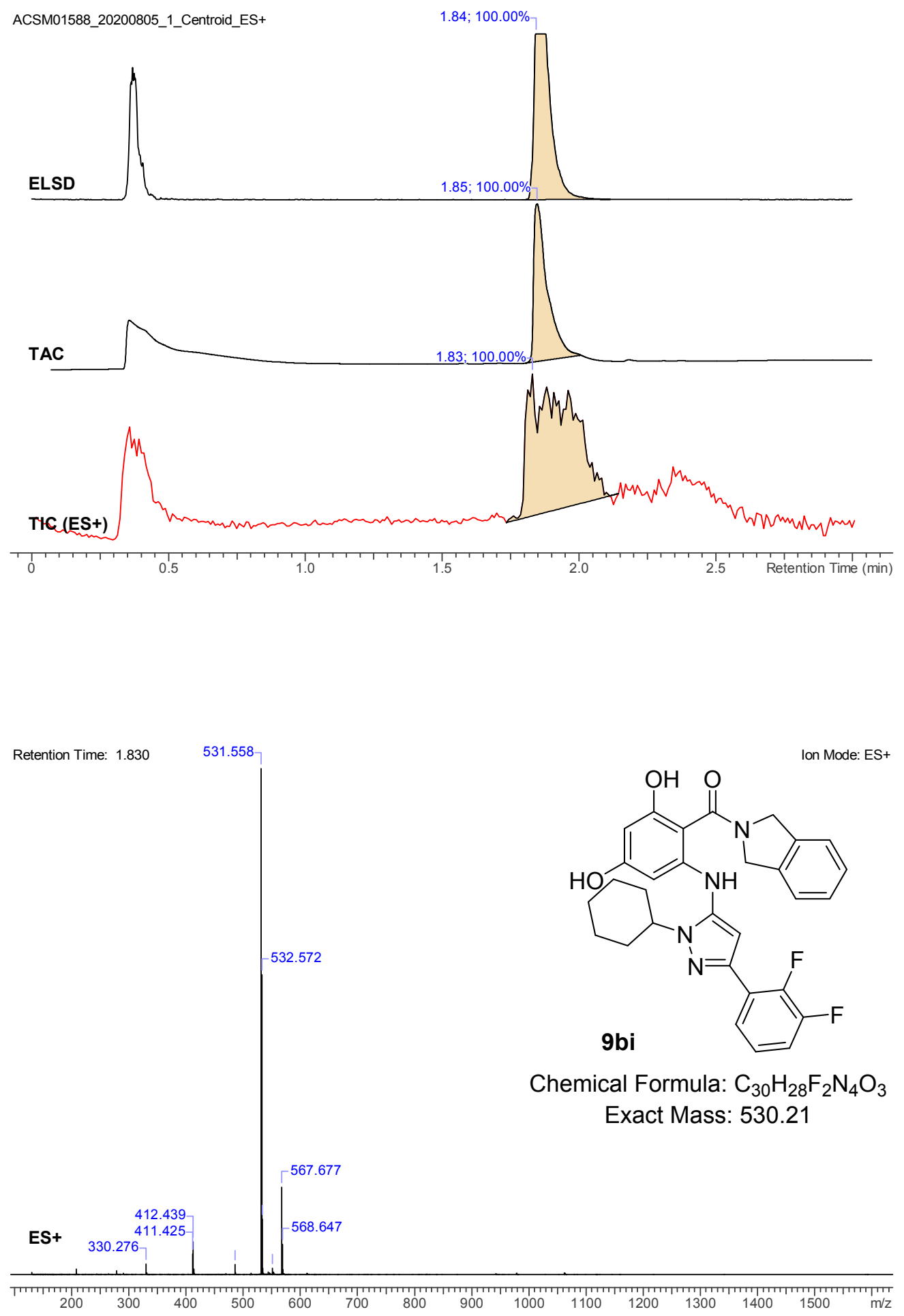